Tarling: Journal of Language Education

Vol. 5, No. 1, Juni 2021

http://ejournal.iainpurwokerto.ac.id/index.php/tarling/index

\begin{tabular}{|ll|l|}
\hline Submitted $:$ 2020-08-19 & Accepted : 2020-09-02 \\
\hline Revised $: 2020-09-23$ & Published $: 2021-07-02$ \\
\hline
\end{tabular}

\title{
Millennials, Technology, and English Language Teaching
}

\author{
Nurul An-Nisa ${ }^{1}$; Giarni Alfi Astika ${ }^{2}$; Tono Suwartono ${ }^{3}$ \\ ${ }^{123}$ Universitas Muhammadiyah Purwokerto, Indonesia \\ 1.annisanurul889@gmail.com; ${ }^{2}$ gigiastika19@gmail.com; \\ ${ }^{3}$ suwartononewton@gmail.com
}

\begin{abstract}
Abstrak
Saat ini perkembangan teknologi semakin maju. Keadaan ini menuntut generasi milenial untuk mengaplikasikan teknologi di setiap bidang kehidupan. Hal tersebut membuatgenerasimilenial sangat bergantung padateknologi. Teknologimemegang peranan penting dalam konteks pendidikan khususnya dalam pengajaran bahasa Inggris. Kehadiran teknologi memudahkan guru dan siswa untuk mendapatkan materi pembelajaran dan mengembangkan petunjuk pembelajaran. Mereka dapat menggunakan teknologi media apapun untuk menunjang keberhasilan kegiatan belajar mengajar. Terdapat berbagai aplikasi media yang dapat digunakan untuk membantu proses pengajaran bahasa Inggris baik di dalam kelas maupun di luar kelas. Dalam penggunaan aplikasi media elektronik dalam proses pembelajaran disebut e-learning. Guru harus mampu memilih kegiatan yang kreatif dan inovatif. Hal tersebut dapat membuat kegiatan mengajar menjadi lebih menarik dan tidak membosankan. Artikel ini membahas tentang hubungan milenial, teknologi, dan pengajaran bahasa Inggris untuk menciptakan guru-guru hebat di masa depan.

Kata kunci: milenial, teknologi, pengajaran bahasa inggris, e-learning
\end{abstract}




\begin{abstract}
At present, the development of technology has increasingly advanced. This situation requires millennial to apply technology in every area of life. It makes millennial generation very dependent on technology. Technology plays an important role in education context especially in English language teaching. The presence of technology makes teachers and students easier to get learning material and develop learning instructions. They can use any media technology to support the success of teaching and learning activities. There are various media applications that can be used to help the English teaching process both in the classroom and outside the classroom. In the use of electronic media applications in the learning process called e-learning. Teachers must be able to choose activities that are creative and innovative. It can make teaching activity more interesting and not get bored. This article discusses about the relationship among millennial, technology, and English language teaching to create great teachers in the future.
\end{abstract}

Keywords: millennial, technology, English language teaching, e-learning

\title{
A. Introduction
}

In this globalization era, millennial generation demand not to be separated from technology. Technology provides the ease for people to do something. In everyday life, people use technology as a tool to facilitate their work easier. Millennial are individuals born between 1980 and 2000 . They are called millennials because of their closeness to the millennium and being raised in a more digital age (Kaifi, et al. 2012). They were raised with technology that allows constant connection to friends and family. Text and instant messaging, cell phones, beepers, blogs and social networking are a normal part of their everyday life and allow connection anytime and anywhere (Kraus and Sears, 2008). Millennial generation is very close to technology, they cannot be separated from technology and internet. Therefore they are very influential in technological development and hopefully they can bring positive influence to the development of a better world. Starting from now, they must adapt to the development of increasingly advanced world, so millennial must be clever to take advantage 
of technology, especially digital technology. Because, digital technology plays an important role for millennial in order to create a brighter future and itbecame a more competent and quality generation.

In the other hand, technology plays an important role in education context. Since technology cannot be separated with education,teachers or educators are expected to be able to take advantages oftechnological development. In this case is to facilitate students accessing the knowledge they need. Technology is changing the ways language teachers teach and that language learners learn and consequently is playing an increasingly centralrole in curriculum implementation (Warschauer and Meskill, 2000). Internet provides many education sources that can be used to help students learn English. It can be access 24 hours even when the class is end. Today's generations are very familiar with digital media. By applying digital media that is connected with internet, any information can be easy accesseverywhere. The implementation of technology by millennial generations in language teaching also affect in increasing learning quality. In addition to that, Ahmadi (2017) states that one of the important elements for learning is the method that instructors use in their classes to facilitate language learning process. This becomes an opportunity for millennial teachers to upgrade teaching process. Solanki and Shyamleel (2012) support the view that language teaching method has been changed due to technology.

Technology has been used to improve and help English Language Teaching. Millennial invite societies to be familiar with the development of technology as well as the upgrading ways to communicate with others. This era makes you impossible to avoid English as a foreign language (Amiruddin and Suparti, 2018). Therefore, the role of digital technology is very helpful in learning activities or other activities to be more interesting and more modern. Teachers can also teach and motivate students to try to develop by using technology media in their learning activities. As stated by Ahmadi (2018), Technology has always been an important part in the 
teaching and learning environment. It is an essential part of the teacher's profession through which they can use it to facilitate learner's learning. Technological development can bring millennial being better teacher in the future.

\section{B. Discussion}

\section{Millenials}

Millennials are human population after generation X (born between mid-1960 and early 1980), so they are individuals born between 1980 and 2000. If we see from the age group millennial generation is a generation currently around 20-40 years. According to Yuswohady in the article Millennial Trends (2016), millennial generation is a generation born in the beginning of the year 1980 to 2000. This generation is frequent also known as Gen-Y, Net Generation, Generation WE, Boomerang Generation, Peter Pan Generation, and others. Millennial generation has grown up with a majority of the technological advances such as computer and internet. This generation uses a lot of communication technology instant like e-mail, SMS, instant messaging, and social media like Facebook, Twitter, Instagram, and others, so in order words the generation $\mathrm{Y}$ is the generation that grew up in the booming internet era (Hidayatullah, et al. 2018). Based on that statement, because they were born in an increasingly advanced era, their behaviour is dependent on technology in searching or gathering any information. In addition, they also use technology to facilitate their individual needs such as in the field of work, business, education, and others.

\section{Shaped by Culture}

The existence of technology and information in the past or before the millennial generation is very different from the situation of the current millennial generation. In ancient times everything was completely simple caused by several factors, such as low income, very limited necessities of life, and underdeveloped technology. Beside that, the existence of 
information flow was not fast or still massive compared to today. And also the state of the technology was not yet modern like now or in other words it was still very simple. However, it is very different from people who born in millennial era, they are born in a state of the world that is completely practical and instant in various aspects of life.

Now, the millennial situation is all practical and instant because it is supported by rapidly developing technology. There are other differences that arise between millennials and previous generations, which are related to cultural problems / everyday lifestyle. For example, in this millennial era the level of consumption is very high, they really like to hangout with friends, there are many online bussiness. In addition, they always have new and creative ideas that are very influential on all sides of their lives. They are also good at using all forms of technological media, especially in the use of digital or electronic media such as smartphone and laptop. Therefore, all differences in circumstances and behavior can be interpreted that the development of an increasingly advanced era will also have a different impact on changing someone's behavior. So, we can conclude from all statements that millennials are individuals shaped by cultural developments from time to time.

\section{Millennial Attributes: Mobile, Collaborating, Connecting}

At this time, millennial continues the previous generation (Gen-X) in the use and utilization of digital technology, but now the level of use and utilization of digital technology by millennial generation is growing rapidly. The tools and media they use are more modern. Therefore, to support this they certainly have identical attributes to carry out their activities in surfing the virtual world by using various technological media. Related to millennial attributes, they are identical with the use of mobile such as Smartphone, laptop, computer, internet, resourceful, search engine, and gaming. As we now, that is all cannot be separated from millennial. So, with the use of these millennial attributes millennial can collaborating and connecting each other quicker and more effectively. Smith and Nichols 
(2015) states millennial enjoy working in teams and are more tolerant than prior generation, they have been raised on sports team, standardized testing, and group learning. So, of course they can more easily collaborating and connecting virtually and instantaneously with anyone through any platform wherever and whenever they are directly or without having to face-to-face.

\section{Technology and Connectedness}

In this modern era, educators are expected to be able to use the technological development in their teaching practices. Technology connected to the internet directly gives positive impacts. Teachers and students can create, share, and receive information with each other. As digital technology advances rapidly, it certainly must be put to good use by millennial. The technology and media used by millennial during their lives influence the way they learn and their learning expectations (Bajt, 2011). So, they must be able to take advantage of existing technology properly because it can affect their lives to be better. If a millennial have the ability to manage digital technology then it will be a positive value for them in dealing with the working world. They can use it according to their needs and their line of work. Because smart millennial are millennial who can take advantage of social media for their daily needs such as work, business and education.

\section{Connect and Share Information}

Currently, there are many technology-based media available in the internet so that all activities can run easily and practically. According to Raja (2018), the use of the internet is like a blessing for students. Internet changes the difficulty to be ease. Faizi, et al (2013) explains that social media can improve communication not only between students and teacher but also among students. Facebook, YouTube, Instagram, Twitter, and LinkedIn are accessed every day for their personal, social, and media activities (Budiman, 2020). Social media was created not without reason. 
But, it has several benefits for millennial generation such as share about any information, teaching contents, collaborating with other people in various parts of the world. Millennials are also expected to be able to use a Smartphone, a laptop computer, the internet so they can more easily access social media and easier to interact with others. This is characterized by the technology, the ease of access to all information from all contexts, including in the context of education.

\section{Teaching Contents}

Technology brings the passive education to be active education like now. Creativity in the use of technology in the language classroom has resulted in teaching innovations (Suwartono, 2018). Ease of access information not only provides comfort for students in getting learning materials. However, teachers can also use it as a means to develop learning instructions to be applied in the classroom over the internet. Many platforms provide that kind of information, some primary sources of materials are sites such as OneStopEnglish at http://www.onesstopenglish.com/ which features plenty of materials and lesson plans for regular use and the $\mathrm{BBC} /$ British Council collaboration also has plenty of resources on its Teaching English site at http://www.teachingenglish.org.uk/(Dudeney, 2007: 152).In addition to developing new ideas aboutlearning materials, teachers can also find the right strategy in learning. It is very useful to improve the quality of the material to be taught to the students.

The abundant English language media resources are also available from some other sites or some online newspaper and magazines as the following (Warschauer, Shetzer and Meloni, 2002: 23-24).
a. Digital Libraries Initiative (http://dli.nsf.gov).
b. Literature Online (http://lion.chadwyck.com).
c. Newpapers Online (http://www.newspapers.com)
d. The Times (http://.the-times.co.uk)
e. The New York Times (http://www.nytimes.com) 
f. The Washington Post (http://www.washingtonpost.com)

g. The Wall Street Journal (http://www.wsj.com)

h. The Sydney Morning Herald (http://smh.com.au)

i. Time (http://www.time.com)

j. Newsweek (http://www.newsweek.com).

k. CNN.com (http://www.cnn.com)

1. BBC Online (http: www.bbc.co.uk)

m. The New York Times Learning Network

n. (http://www.nytimes.com/learning)

o. BBC School Online (http:// bbc.co.uk/education/schools), and

p. Learning Resources at http://literacynet.org/cnnsf which is developedjointy by CNN San Francisco and Western/Pacific Literacy Network.

\section{Future Teachers}

The quality of education also depends on the teachers themselves. Teachers are the role model of students. Because of that, one of the main requirements to prepare great generation is having qualified teachers.Future teachers must heave sensitivity in utilizing technological developments. The prospective teacher will bring great changes in the education. The main goals as future teachers are providing an authentic, creative and innovative teaching to the students. Teachers, modernize ourselves and start using social networks. They make the material for learning more accessible to students and to encourage discussion among the students.

Teachers should be creative and innovative in implementing learning material. According to Suwartono (2016) it is fair to say that creativity is an important factor in achieving success, including success in English language teaching /ELT. Teachers and students can use various media to learn English applications such as Hello English Duolingo, blogs, and other applications that are currently widely available on the internet to explore their knowledge. With the hope for teachers or future teachers can make learning material more interesting and to adapt to any classroom activities. 


\section{English Language Teaching}

Technology also play a huge impact in English language teaching. As English is an international language that is used to communicate with people all over the world so that English is very important (Ma'rufah, 2018). The rapid technological development supports teaching activities, especially in teaching language. Teachers should find methods of applying technology as a useful learning instrument for their learners although they have not learnt technology and are not able to use it like a computer expert (Ahmadi, 2018). English language teaching involving technology can facilitate the teachers in the learning process to be easier and effective. Technology-enhanced teaching environment is more effective than lecturebased class. According to Faizi, et al (2013) many students often complain of getting bored or intimidated at school, the dynamic and participatory nature of many social media resources could be used to engage or reengage bored or shy students.Teaching activities carried out by a teacher are not an easy task, because they play an important role in the success of the education process. As stated by Risani (2020), teaching is a process to share knowledge among teachers as facilitators and students. The role of the teacher in teaching is very important to achieve student success in learning. To achieve the purpose of teaching, the teacher should be creative in choosing the materials and strategies of teaching in order to make students understand the knowledge easily (Suwartono, et al. 2019).Teacher acts as real parents of the pupils. They mostly aimed to make the learner be a good man in society which is also the purpose of education (Suresh and Srinivasan, 2014). But on the other hand, their role is not only to teach and educate their students but they must also be good at creating good and effective learning environments. Therefore, they must be able to manage the class well by creating a variety of learning activities in class that are interesting, creative, and accordance with the material being taught so that learning objectives can be achieved. 
To support that success, the teacher can create a learning environment by making interesting activities such as games, using teaching aids and available facilities, and even using various other technological and internet media. So, the teacher not only teaches but also makes the learning environment, they can facilitate students in carrying out learning activities, because a good learning environment can make the learning process take place effectively and conducive. The intended learning environment is not just students and teachers, but everything that exists or related to the place of learning. So, we can know that the teaching process is the interaction between teachers, students, friends, and the surrounding environment, in order to create an environment for students to learn where they can obtain information, knowledge, and skills.

In creating a good environment for students to learn, it is very necessary to have interesting teaching and activities in the classroom. Currently, teaching and learning activities can not only be done in school by only explaining the material, but it can also be done in outside of school by using e-learning. Digital methods that use electronic devices and networks to help learning between teachers and students are often referred to e-learning. Oye (2012) states thate-learning refers to using electronic applications and processes to learn. E-learning applications and processes include Web-based learning, computer-based learning, virtual classrooms and digital collaboration. Currently, the e-learning method began to be widely used by several schools and colleges. E-learning is also called webbased learning, online learning, distributed learning, computer-assisted instruction, or internet-based learning (Jethro, et al. 2012). Now, teachers and students can use e-learning according to their needs to help them learn. The use of e-learning is currently growing rapidly and it has various benefits for them. One of the benefit of e-learning is it makes e-learning more flexible and practical. So, it will increase students' motivation to learn because they can carry out teaching and learning activities wherever and whenever they are. 


\section{E-Learning}

In e-learning teacher and students can use various media for teaching or for learning English by using many applications, website, or social media such as Hello English, Duolingo, Lingbe, Memrise, Busuu, Blog, Zoom, Schoology, and other application that currently widely available on the internet to explore their knowledge. These virtual technology devices is one of the right tools to support or helping teachers when teaching students and this one matches with condition right now that we called millennial or 4.0 era (Risani, 2020). As stated by Suwartono (2018), teachers are demanded to play their roles as facilitator, manager, and advisor by keeping up with the development of technology in digital area. In addition, to delivering learning material a teacher can also be a coach in selecting and using teaching aids in learning activities. With the hope for teachers or future teachers can make learning material more interesting and to adapt any classroom activities when teaching students so it doesn't make students feel bored. Besides that, teacher can also give examples or motivate to students to use various types of media technology to facilitate learning, teaching, and to complete their work. With the aim students can became a millennial generation who are creative, innovative, and ready to face the working world.

\section{Conclusion}

In view of the discussin above, it very well may be presumed that in the past few years, technology is individuals' way of life. It changes everything to be easier. The technological development surrounds millenials life. Milleanial grow by technology and technology is the part of millenial's. Millennial age has grown up with a majority of the technological advances such as PC and web. Beside that, technology also has a high position in improving education quality. Millenial as future teachers have to be able to use the various kind of technology to be implemented in English language teaching. 
There are many internet platforms that can be used as media for teaching English. Teacher and students can use various media for teaching or for learning English by using many applications, website, or social media such as Hello English, Duolingo, Lingbe, Memrise, Busuu, Blog, Zoom, Schoology, and other application that currently widely available on the internet to explore their knowledge. Teachers and students do not need to have face to face meeting. It is called as e-learning. The use of e-learning certainly has various benefits for teachers and students. For teacher, they can develop any learning activities. For students, it can make them to become millennial generation who are creative, innovative in utilizing technological media.

\section{References}

Ahmadi, M. R. 2017. "The impact of motivation on reading comprehension." International Journal of Research in English Education. http://www. ijreeonline.com

Ahmadi, M. R. 2018. "The Use of Technology in English Language Learning: A Literature Review." International Journal of Research in English Education, 3(2): 116-125. doi: 10.29252/ijree.3.2.115

Amiruddin, M., and Suparti, T. 2018. "Madurese Millennial Students' Anxiety in Learning English." Journal of Intensive Studies on Language, Literature, Art, and Culture, 2(2): 34-41.

Bajt, S.K. 2011. "Web 2.0 technologies: application for community colleges." New Directions for Community Colleges, 2011(154): 5362. doi: $10.1002 / \mathrm{cc} .446$.

Budiman, Asep. 2020. "ICT and Foreign Language Learning: An Overview." Tarling: Journal of Language Education, 3(2): 245-267. doi: https:// doi.org/tarling.v3i2.3913

Dudeney, G. 2007. "The Internet and the Language Classroom." Second 
Edition. Cambridge: Cambridge University Press.

Faizi, R., Afia, A. E., and Chiheb, R. 2013. "Exploring the Potential Benefits of Using Social Media in Education." iJEP, 3(1): 50-53.

Hidayatullah, S. et al. 2018. "Perilaku Generasi Millennial dalam Menggunakan Aplikasi Go-Food." Jurnal Manajemen \& Kewirausahaan, 6(2): 240-249.

Jethro, O. O., Grace, A. M., and Thomas, A. K. 2012. "E-Learning and Its Effects on Teaching and Learning in a Global Age." International Journal of Academic Research in Business and Social Science, 2(1): 203-210.

Kaifi, B. A., Nafei, W. A., Khanfar, N. M., and Kaifi, M. M. 2012. "A multigenerational workforce: managing and understanding millennials." International Journal of Business \& Management, 7(24): 88-93. doi: 10.5539/ijbm.v7n24p88.

Kraus, S., and Sears, S. 2008. "Teaching for Millennial Generation: Student and Teacher Perceptions of Community Building and Individual Pedagogical Techniques." The Journal of Effective Teaching, 8(2): 32-39.

Ma'rufah, Desi. Wijayanti. 2018. "Teachers' Ways in Maximizing Student Talking Time (STT) in EFL Classroom." Tarling: Journal of Language Education, 1(2): 33-45.

Oye, N. D., Salleh, M., and Iahad N. A. 2012. "E-Learning Methodologies and Tools." (IJACSA) International Journal of Advanced Computer Science and Applications, 3(2): 48-52.

Raja, R., and Nagasubramani, P. C. 2018. "Impact of Modern Tehnology in Education." Journal of Applied and Advanced Research, 3(1): 533535.

Risani, T. D. 2020. "Writing News Item in English Language Teaching Context: Line Apps Platform for Senior High School Students.” The 
Nurul An-Nisa; Giarni Alfi Astika; Tono Suwartono

Journal of Ultimate Research and Trends in Education, 2(1): 24-28.

Smith, T. J., and Nichols, T. 2015. "Understanding the Millennial Generation." Journal of Business Diversity, 15(1): 39-47.

Solanki, D., and Shyamleel, M. P. 2012. "Use of technology in English language teaching and learning: An analysis." 2012 International Conference on Language, Medias and Culture IPEDR vol. 33(2012)@(2012)IACSIT Press, Singapore. 150-156.

Suresh, K., and Srinivasan, P. 2014. "Effective Teaching Makes Successful Teacher." EPRA International Journal of Economic and Business Review, 2(11): 55-61.

Suwartono. 2016. "Teacher's Creativity in ELT." International Seminar on English Language Teaching (ISELT 2016), 1-8.

Suwartono, T., and Aniuranti, A. 2018. "Digital Teaching Tools in 21st

Century EFL Classroom: Are Our Teachers Ready?." Journal of English Language, Literature, and Teaching, 3(2): 57-62.

Suwartono, T., Karini, Z., and Pungki, O. D. 2019. "Teacher Approaches to Teaching a Large EFL Class.” Khazanah Pendidikan: Jurnal Ilmiah Kependidikan, 13(1): 58-70.

Warschauer, M.,and Meskill, C. 2000. "Technology and second language learning." In J. Rosenthal (Ed.), Handbook of undergraduate second language education. Mahwah, New Jersey: Lawrence Erlbaum. 303318.

Yuswohady. 2016, January 17. “Millennial Trends 2016.” Retrieved on 19 July 2020, from: http://www.yuswohady.com/2016/01/17/millennialtrends-2016/ 